\title{
Analisis Senyawa Minyak Atsiri Fuli Pala Secara GC-MS dan Uji Aktivitas Antibakteri Terhadap Ecschericia coli dan Staphylococcus aureus
}

The Analysis of Nutmeg Mace Essential Oil Compound Using GC-MS and Antibacterial Activity Test Toward Ecschericia coli and Staphylococcus aureus

Hery Muhamad Ansory1, Prietta Khania Kusuma Putri², Nur 'Aini Hidayah², Anita Nilawati ${ }^{1}$

1. Farmasi Major, Universitas Setia Budi, Surakarta

2. Anafarma Major, Universitas Setia Budi, Surakarta

Corresponding author: Nur 'Aini Hidayah: Email: nurainihidayah04@gmail.com

\begin{abstract}
ABSTRAK
Telah dilakukan isolasi minyak atsiri dari fuli pala dengan menggunakan metode destilasi air. Analisis kandungan senyawa minyak atsiri fuli pala dilakukan dengan GC-MS. Hasil analisis kandungan senyawa minyak atsiri didapatkan 4 senyawa dominan yaitu $\alpha-$ pinene, sabinene, 2- $\beta$-pinen, dan miristisin. Kualitas minyak atsiri fuli pala dilihat dari perbandingan antara minyak hasil isolasi dengan standar SNI. Minyak atsiri fuli pala tidak memenuhi standar SNI dalam hal berat jenis. Namun, mempunyai kandugan miristisin yang relativ tinggi yaitu 30,82 \%. Menurut Agusta (2000), minyak atsiri merupakan antibakteri yang baik. Uji aktivitas antibakteri dilakukan dengan metode dilusi dan difusi. Hasil uji dilusi tidak dapat disimpulkan nilai KHM dan KBM. Hasil uji difusi menunjukkan bahwa minyak atsiri fuli pala dengan konsentrasi 7,50 \% dapat menghambat Stapylococus aureus dengan rata-rata diameter zona hambat sebesar 9,25 mm. Sedangkan pada bakteri Ecschericia coli mempunyai rata-rata diameter zona hambat sebesar 7,375 mm.
\end{abstract}

Kata kunci: Minyak atsiri, Fuli, GC-MS, Difusi, Dilusi

\begin{abstract}
Isolation of essential oil from nutmeg mace by using water distillation method had been done. The content analysis of the nutmeg mace essential oil compound was done by using GC-MS. The analysis result shows that there are 4 dominant compounds they are $\alpha$ pinene, sabinene, 2- $\beta$-pinen, and myristicin. The quality of nutmeg mace essential oil is seen from the ratio of oil resulted from isolation with the SNI standard. Nutmeg mace essential oil does not fulfill the SNI standard in term of specific weight. However, it contains a relatively high among of myristicin which is $30.82 \%$. According to Agusta (2000), essential oil is a good antibacterial. The antibacterial activity test was done by using the dilution and diffusion method. The result of the dilution test could not conclude the value of KHM and KBM. The diffusion test result shows that nutmeg mace essential oil with $7.5 \%$ concentration is able to inhibit the growth of Stapylococus aureus with the average inhibition zone diameter of $9.25 \mathrm{~mm}$. While on the Ecschericia coli bacteria, it has the average inhibition zone diameter of $7.375 \mathrm{~mm}$.
\end{abstract}

Keywords: Essential oil, Mace, GC-MS, Diffusion, Dilution 


\section{INTRODUCTION}

Infection is one of the most crucial health problems in Indonesia. Bacteria is one of the microorganism that causes infections. There are many kinds of infection-causing bacteria or pathogen bacteria. Two of them are Stapylococus aures and Escerichia coli bacteria (Volk \& Wheeler, 1990).

The society uses antibiotics to cure infections caused by those two bacteria. The excessive use of antibiotics may lead to resistance in a microorganism. Once a microorganism becomes resistant to an antibiotic, its growth will be hard to be inhibited. A natural antibiotic is needed to inhibit or kill a microorganism without making it to be resistant.

Nutmeg is Indonesian local plant often utilized as traditional medicine and spices. Nutmeg is the main product of nutmeg plant. The parts of a nutmeg consist of flesh, seeds, and mace. Mace is the skin of nutmeg seeds with red color that covers the seeds. The utilization of nutmeg mace is still relatively low compared to that of the nutmeg itself. It makes the economic value of nutmeg mace still low.

The parts of nutmeg contain essential oil. Nutmeg mace can produce $4.77 \%$ essential oil (Ansory, 2014). The essential oil from nutmeg mace contains several compounds. According to Agusta (2000), the dominant chemical compounds contained in nutmeg mace oil consist of $\alpha$ Pinena, $\beta$-pinena, limonene, $\beta$-Linalool, 4 metil-1- (1 - metiletil) -3- sikloheksan-1 -ol, safrol, and myristicin. Most of the essential oil is also strong antibacterial and antifungal (Agusta, 2000). Based on the background, a research about the content of nutmeg mace essential oil and the antibacterial activity toward Escherichia coli and Stapylococus aureus can be made.

\section{METHODS \\ Materials}

Materials used in this research are nutmeg mace sample, aquadestila, cooking oil, natrium sulphate-anhydrate, N-hexane (Merck) pa, Acetone (Merck) pa, MHA pa media, BHI pa Media, EA pa Media, VJA pa mMedia, biochemistry test media, 0.5 Farlan MC Standard, Tetraciclin $\mathrm{HCl}$, Amoxicillin, pure germ of Ecschericia coli and Stapylococus aureus collection from Universitas Setia Budi.

\section{Methods}

The samples used in this research were fresh nutmegs, harvested in Bergas, Semarang Regency. The nutmeg samples was sorted into 3 parts which are flesh, mace, and seeds. Isolation of essential oil by using water distillation method and analyzed by using GC-MS. The antibacterial analysis includes:

\section{Dilution test}

The antibacterial test of essential oil from nutmeg mace was done by using the dilution method. A series concentrate of essential oil is $60 ; 30 ; 15 ; 7.5 ; 3.75 ; 1.875 \%$ with acetone dissolvent. Positive control by using suspense of bacteria and negative control is essential oil from nutmeg mace.

\section{Diffusion test}

The antibacterial test of essential oil from nutmeg mace was done by using the diffusion method. Diffusion test was done using the paper disk method. A series concentrate of essential oil is 30; 15; $7.5 \%$ with acetone dissolvent. Positive control by using Tetracycline $\mathrm{HCl}$ and negative control is acetone dissolvent

\section{RESULT AND DISCUSSION}

The nutmegs from Bergas, Semarang Regency, Central Java were chosen as the samples if they had brownish yellow color. The mace nutmeg sample preparation was done by drying it by using the wind-drying method. The wind-drying method is better than the other methods because it does not remove the important compound from the nutmeg mace essential oil (Shopia G.Sipahelut and Ivonne Telussa, 2011). The 
drying was used to reduce the water level and deactivate the enzyme inside the samples and also to prevent the enzymatic reaction. The weight of each part of the fresh nutmegs separated was (Table I).

\section{The result of essential oil isolation}

The research of Ansory (2014), isolation of nutmeg mace essential oil was rendemen $4,77 \%$, while in this research was rendemen $3,56 \%$.

The quality of nutmeg mace essential oil resulted from the isolation was then compared to the quality of nutmeg oil according to the quality requirement of Standar Nasional Indonesia (SNI) (Technical Committee of Chemical Technology, 2006), it is done to determine the quality of the nutmeg oil resulted from the isolation (Table III).

The comparison result shows that the quality of nutmeg mace oil did not fulfill the SNI standard in term of specific weight. The specific weight value of the nutmeg mace oil resulted from isolation was 0.926 while the one based on SNI is $0.88-0.91$. The other test parameters had fulfilled the quality requirement based on SNI. The myristicin content in the nutmeg mace essential oil was quite high compared to the one in the research of Khania (2018) which was $6.13 \%$.

The isolated essential oil was then tested using GC-MS method to determine the compounds content. The essential oil compound will be isolated by the chromatography gas (GC) based on its boiling point. Each of the isolated components will be put into spectrophotometry mass (MS) and will be detected by the detector from MS. The chromatogram result from nutmeg mace essential oil analysis is as follows (Figure 1).

The compound content analysis of the nutmeg mace essential oil was done in the dominant compounds in the nutmeg mace essential oil. Dominant compounds are the compounds having greater peak compared to the others. The highest peaks produced were the 4 highest peaks during the retention time: 3.683 ; 4.438; 4.558; and 11.425 minute. The first compound is the compound in the retention time of 3.683 minute (Figure 2).

Based on the MS produced, the molecule mass of the compound is 136 and it can be predicted that the compound has the molecule formula of $\mathrm{C}_{10} \mathrm{H}_{16}$ and based on the MS library, that compound has similar fragment to the $\alpha$-pinene compound. The compound molecule formula prediction can be used to determine the DBE formula of a compound. The $\mathrm{C}_{10} \mathrm{H}_{16}$ compound has the DBE value of 3 , it is predicted that the compound consists of 2 cyclic having 1 double bond. The second compound is the compound in the retention time of 4.438 minute (Figure 4).

Based on the produced MS, the compound molecule mass is 136 and it can be predicted that the compound has the molecule formula of $\mathrm{C}_{10} \mathrm{H}_{16}$, then based on the MS library, that compound has similar fragment to sabinene compound. The difference between the first and the second compound is on the molecule division pattern or compound fragmentation pattern. The compound molecule formula prediction can be used to determine the DBE formula of a compound. The $\mathrm{C}_{10} \mathrm{H}_{16}$ compound has the DBE value of 3 , it is predicted that the compound consist of 1 cyclic having 2 double bonds. Based on the data and the analysis conducted, the suggested fragmentation patter of sabinene compound is (Figure 5).

Based on the produced MS, the compound molecule mass is 136 and it can be predicted that the compound has the molecule formula of $\mathrm{C}_{10} \mathrm{H}_{16}$, then based on the MS library, that compound has similar fragment to 2- $\beta$-pinene compound. The difference between the first and the second compound is on the molecule division pattern or compound fragmentation pattern. The compound molecule formula prediction can be used to determine the DBE formula of a compound. The $\mathrm{C}_{10} \mathrm{H}_{16}$ 
Table I. Gross Weight of Nutmeg Parts

\begin{tabular}{lrc}
\hline Parts & Weight & $\%$ \\
\hline Whole nutmeg & $5000 \mathrm{~g}$ & - \\
Nutmeg flesh & $4000 \mathrm{~g}$ & 80 \\
Nutmeg mace (seeds'skin) & $200 \mathrm{~g}$ & 4 \\
Nutmeg seeds & 800 & 16 \\
\hline
\end{tabular}

Table II. Essential Oil Isolation Result

\begin{tabular}{lcccc}
\hline Gross Weight & Dry Weight & Oil Volume & Oil Weight & Randemen \\
\hline 200 gram & 20,7873 gram & $6,6 \mathrm{~mL}$ & 7,124 gram & $3,56 \%$ \\
\hline
\end{tabular}

Table III. The comparison of nutmeg oil resulted from isolation with the quality requirementof SNI nutmeg oil

\begin{tabular}{lcc}
\hline Test Type & $\begin{array}{c}\text { Quality Requirement of } \\
\text { Nutmeg Oil }\end{array}$ & $\begin{array}{c}\text { Nutmeg Mace Essential Oil } \\
\text { Resulted from Isolation }\end{array}$ \\
\hline Color & Colorless / Pale yellow & Colorless \\
Smell & Typical of Nutmeg Oil & Typical of Nutmeg Oil \\
Specific Weight & $0.88-0.91$ & 0.926 \\
Solubility in ethanol & $1: 3$ & $1: 3$ \\
Myristicin Content & Minimum 10\% & 30.82 \\
\hline
\end{tabular}

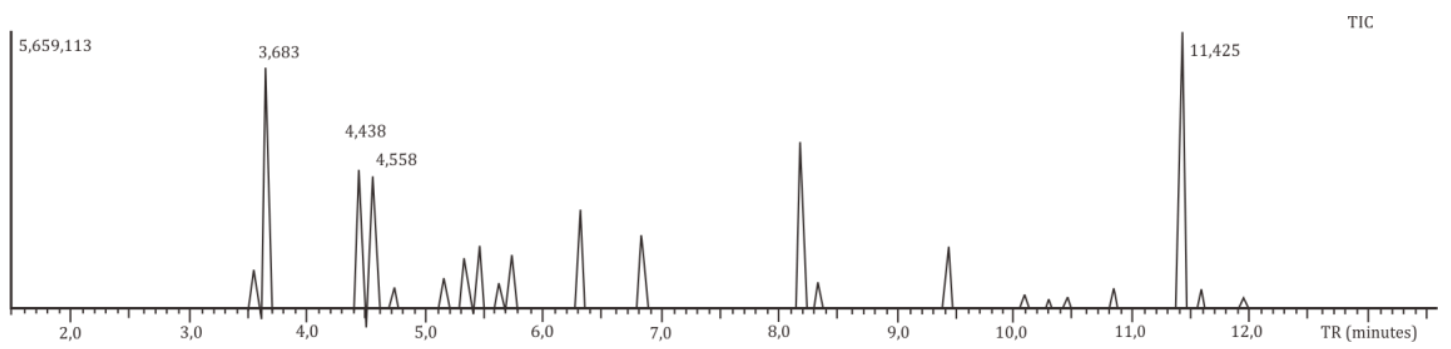

Figure 1. GC Result of Nutmeg Mace Essential Oil

compound has the DBE value of 3 , it is predicted that the compound consist of 1 cyclic having 1 double bonds. Based on the data and the analysis conducted, the suggested fragmentation patter of $2-\beta$ pinene compound is (Figure 7).

Based on the produced MS, the compound molecule mass is 192 and it can be predicted that the compound has the molecule formula of $\mathrm{C}_{11} \mathrm{H}_{12} \mathrm{O}_{3}$, then based on the MS library, that compound has similar fragment to myristicin compound. The 0 atom in this compound is predicted based on the specific fragment pattern from the 0 atom which is $\mathrm{C}=\mathrm{O}$ having the atomic number of 18 . The compound molecule formula prediction can be used to determine the DBE formula of a compound. The $\mathrm{C}_{11} \mathrm{H}_{12} \mathrm{O}_{3}$ compound has the DBE value of 6 , it is predicted that the compound consist of 1 aromatic ring, 1 cyclic, and 1 double bond. Based on the data and the analysis conducted, the suggested fragmentation patter of myristicin compound is (Figure 9).

\section{Antibacterial activity test of nutmeg mace essential oil}

Antibacterial activity test was done by using diffusion and dilution method. The dilution result of nutmeg mace essential oil Shows a negative result or there is no 


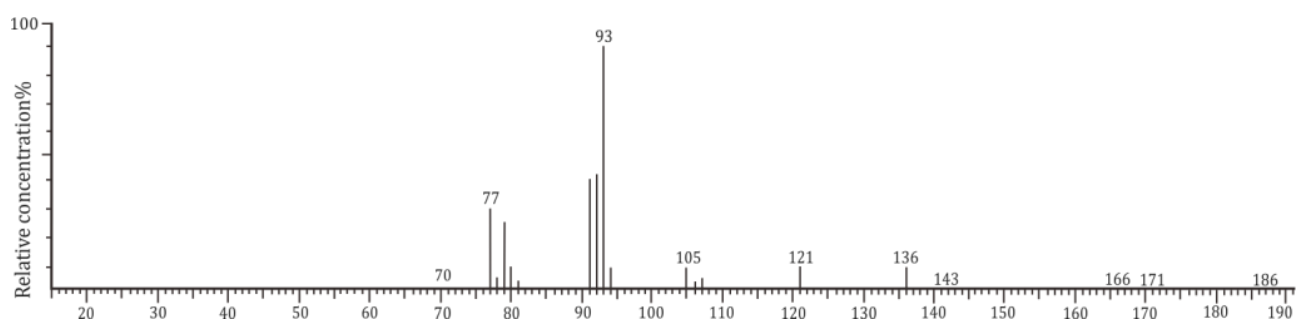

Figure 2.The MS of $\alpha$-pinene compound

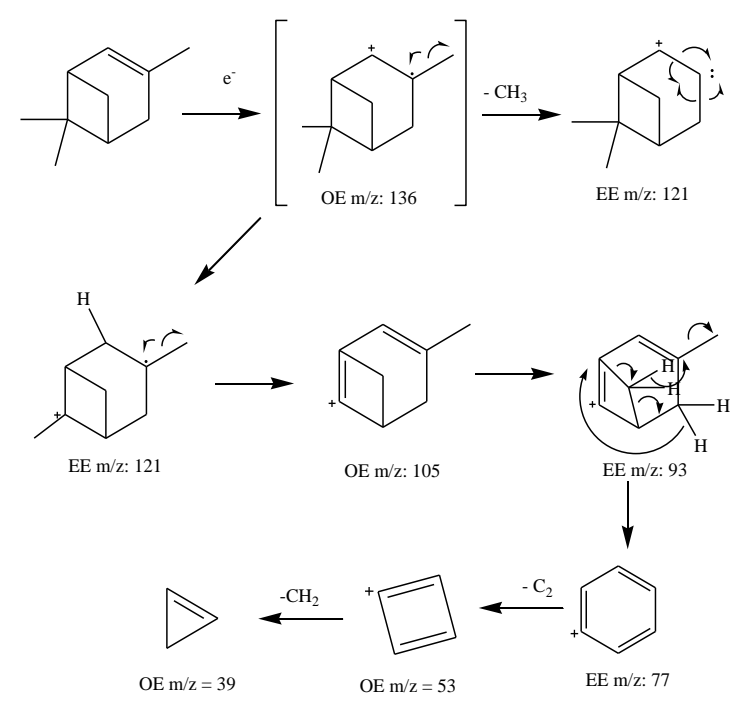

Figure 3. Fragmentation of $\alpha$-pinene compound

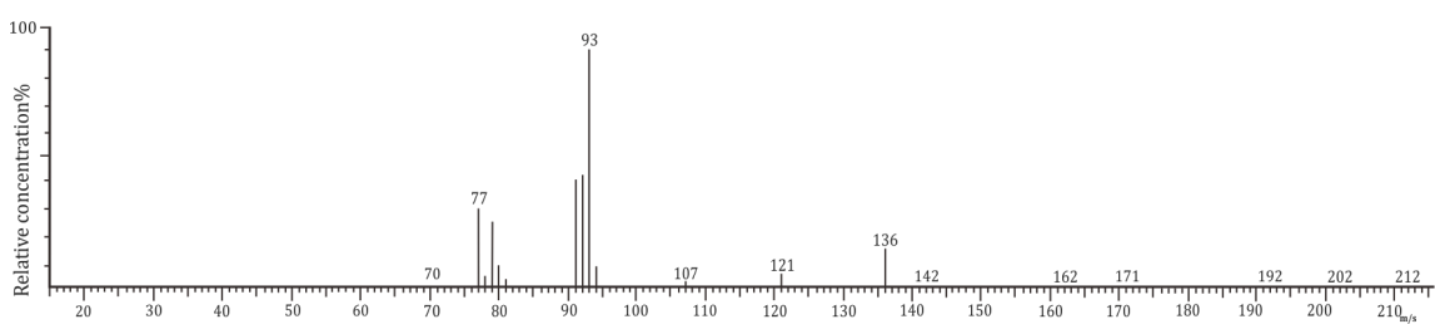

Figure 4.The MS of sabinene compound

bacterial growth found at all. Thus an antibacterial activity measurement was done using different method, which is diffusion method.

\section{Diffusion}

Diffusion is antibacterial activity determining method based on the antibacterial substance diffusion process in the bacterial media. The measurement in this method is based on the diameter or clear zone in the bacterial media. The result of diffusion test is as follows (Table VIII).

According to Pratiwi (2008), the antibacterial inhibition response is quite moderate if it has the inhibition diameter of 6-10 $\mathrm{mm}$. The antibacterial test result shows that the result is around that range, so that the nutmeg mace essential oil has a moderate inhibition response toward the Ecschericia coli bacteria. 


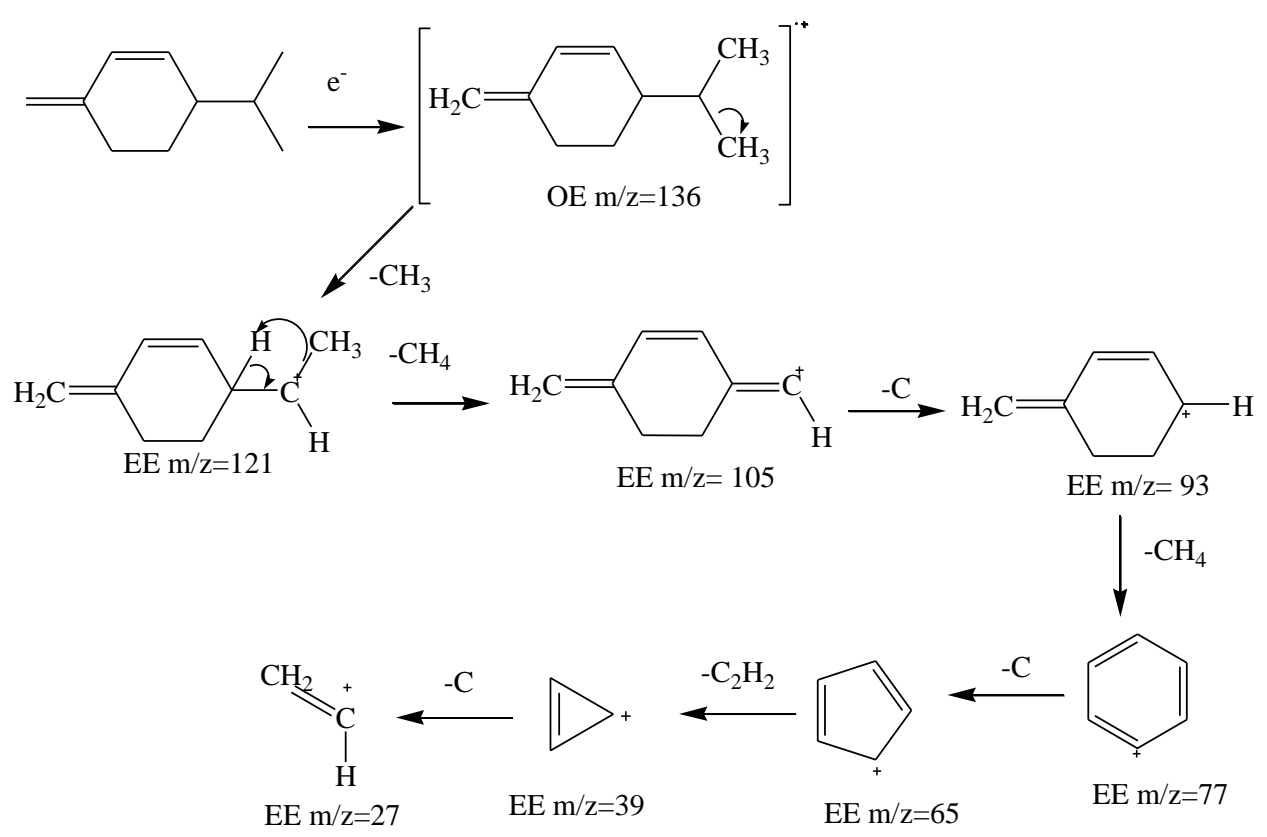

Figure 5. Fragmentation of Sabinene Compound

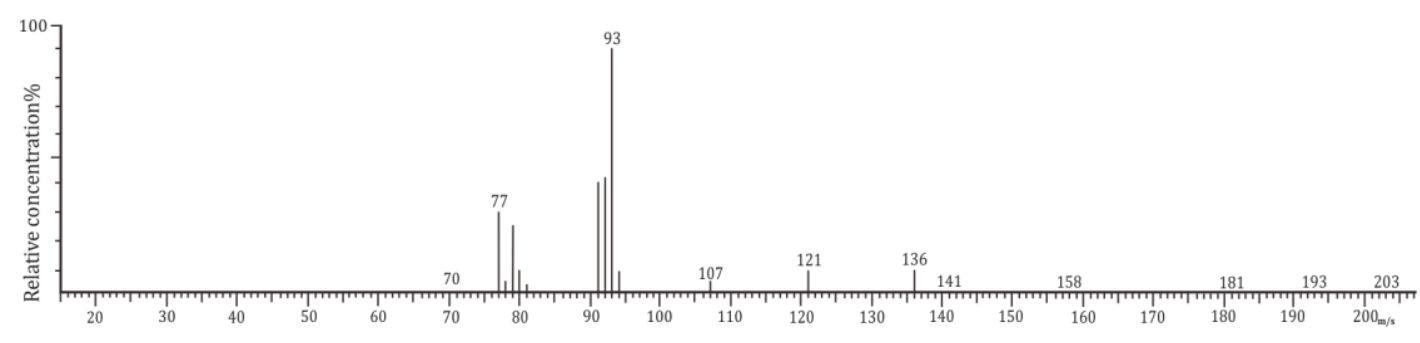

Figure 6 . The MS of 2- $\beta$-pinene Compound

According to Pratiwi (2008), the antibacterial inhibition response is moderate if it has the inhibition diameter of 6-10 $\mathrm{mm}$ and strong if it has the inhibition diameter of $11-12 \mathrm{~mm}$. The antibacterial test result shows the result around 8-14 $\mathrm{mm}$ so that the nutmeg mace essential oil has a moderate to strong inhibition response to Stapylococus aureus bacteria.

It can be concluded from the literary research result that antibacterial activity in nutmeg mace essential oil happens because of certain compounds. There are 4 dominant compounds that have antibacterial activity. Those compounds are $\alpha$ pinen, sabinen, 2- $\beta$ - pinen, dan myristicin. Each of the compound has different antibacterial mechanism. According to the research done by Ji Young Lee and Wansu foto 4x6 Park (2011) about the antiinflation effect of myristicin in 264.7 Macrophages Stimulated RAW with Polyinosinic-Polycytidylic acid that the mechanism of myristicin in inhibiting the inflammation was unknown. However, myristicin can inhibit the inflammation agent. The dominant compounds of nutmeg mace essential oil are classified into monoterpen. Monoterpen compounds have bacterial inhibiting mechanism by inactivating the cell adhesion, enzyme, and activating envelope cell protein (Ya et al., 1988 dalam Gupta et al., 2008).

The $\alpha$-pinen and $\beta$-pinen compounds have difference in term of the speed in inhibiting the bacteria. The $\alpha$-pinen 
Nur 'Aini Hidayah

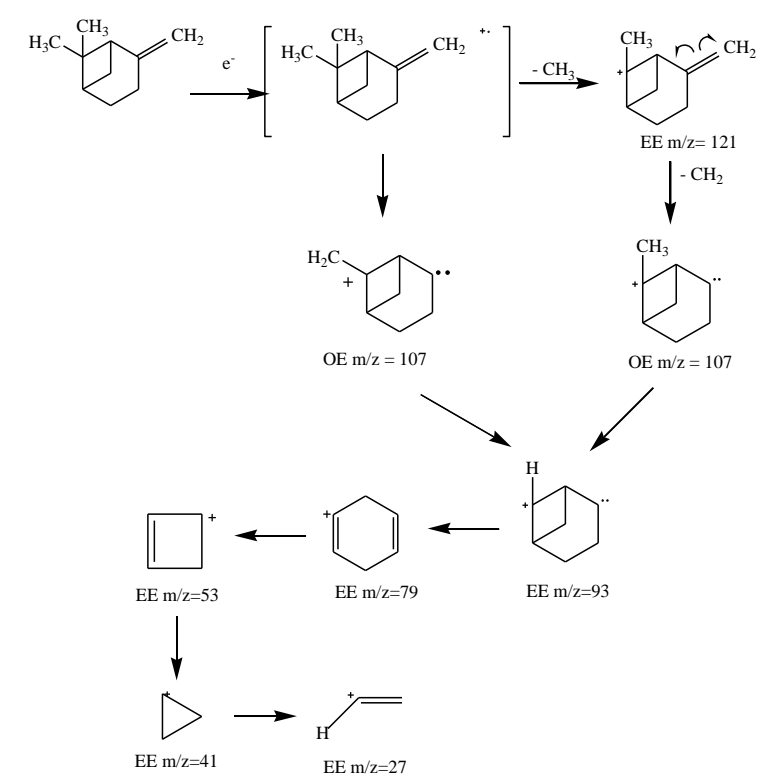

Figure 7.Fragmentation of 2- $\beta$-pinene Compound

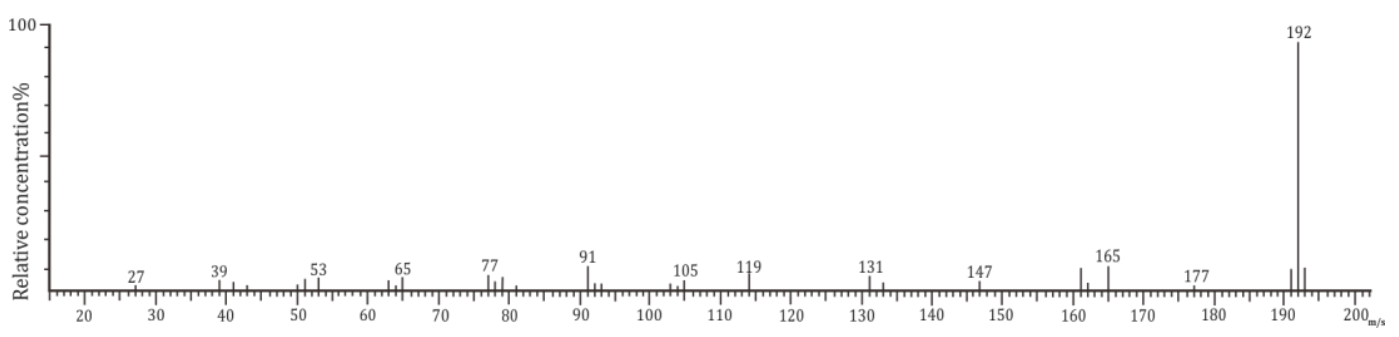

Figure 8. The MS of Myristicin Compound

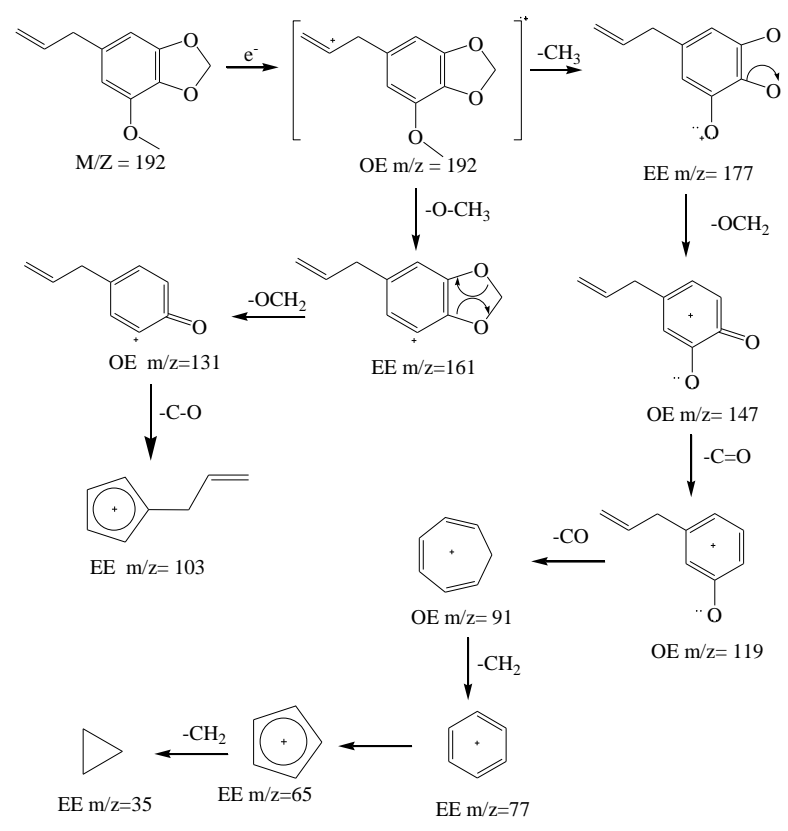

Figure 9. Fragmentation of myristicin compound (Ansory et al., 2014) 
Table VI. Dilution Result of Staphylococcus aureus

\begin{tabular}{cccccc}
\hline No & $\begin{array}{c}\text { Essential Oil } \\
\text { Concentration (\%) }\end{array}$ & $\begin{array}{c}\text { Tube } \\
\text { Result }\end{array}$ & \multicolumn{3}{c}{$\begin{array}{c}\text { Scratching result of the bacterial tube } \\
\text { Staphylococcus aureus in media }\end{array}$} \\
\cline { 4 - 6 } & & Muddy & + & $\mathbf{1}$ & $\mathbf{3}$ \\
\hline 1. & Control + & Clear & - & - & + \\
2. & 60 & Muddy & - & - & - \\
3. & 30 & Muddy & - & - & - \\
4. & 15 & Muddy & - & - & - \\
5. & 7.5 & Muddy & - & - & - \\
6. & 3.75 & Muddy & - & - & + \\
7. & 1.87 & Clear & - & - & - \\
8. & Control - & & & & - \\
\hline
\end{tabular}

Legends:

$(+)$ : An existence of bacterial growth; $(-)$ : No existence of bacterial growth; Control + : contains bacterial suspension; Control - : contains nutmeg mace essential oil

Table VII. Dilution Result of E. coli

\begin{tabular}{cccccc}
\hline & \multirow{2}{*}{$\begin{array}{c}\text { Essential Oil } \\
\text { No }\end{array}$} & Tube Result & \multicolumn{3}{c}{$\begin{array}{c}\text { Scratching result of the bacterial } \\
\text { tube E.coli in media }\end{array}$} \\
\cline { 4 - 6 } & Concentration (\%) & & $\mathbf{1}$ & $\mathbf{2}$ & $\mathbf{3}$ \\
\hline 1. & control + & Muddy & + & + & + \\
2. & 60 & Clear & - & - & - \\
3. & 30 & Muddy & - & - & - \\
4. & 15 & Muddy & - & - & - \\
5. & 7.5 & Muddy & - & - & - \\
6. & 3.75 & Muddy & - & - & - \\
7. & 1.87 & Muddy & - & - & - \\
8. & control - & Clear & - & - & - \\
\hline
\end{tabular}

Legends:

$(+)$ : An existence of bacterial growth; $(-)$ : No existence of bacterial growth; Control + : contains bacterial suspension; Control - : contains nutmeg mace essential oil

Table VIII. Diffusion Result of E. coli

\begin{tabular}{lccc}
\hline Ecschericia coli & $\mathbf{1}$ & $\mathbf{2}$ & Average \\
\hline control + & 21.6 & 21 & 21.3 \\
control - & 0 & 0 & 0 \\
$30 \%$ & 10 & 9 & 9.5 \\
$15 \%$ & 9 & 8.4 & 8.8 \\
$7,50 \%$ & 8 & 6.75 & 7.375 \\
\hline
\end{tabular}

Table IX. Diffusion Result of Stapylococus aureus

\begin{tabular}{lcccr}
\hline Stapylococus aureus & $\mathbf{1}$ & $\mathbf{2}$ & $\mathbf{3}$ & Average \\
\hline control + & 29.5 & 29.25 & 29.25 & 29.3333 \\
control - & 0 & 0 & 0 & 0 \\
$30 \%$ & 11 & 10 & 14.2 & 11.7333 \\
$15 \%$ & 6 & 9.8 & 12.4 & 9.4 \\
$7,50 \%$ & 0 & 8.2 & 10.3 & 6.16667 \\
\hline
\end{tabular}


compound can inhibit positive gram bacteria in 4 hours and kill it after 24 hours, while $\beta$-pinen compound can inhibit the positive gram bacteria in 2 hours (by lowering the number of bacteria's cells) and can eliminate the bacteria's core in 8 hours (Medeiros Aristides Leite et al., 2007).

\section{CONCLUSION}

Based on the research it can be concluded that nutmeg mace contains essential oil with 4 main component compounds which are $\alpha$-pinen, sabinen, $\beta$ pinen, and myristicin, with ones being the highest levels are $\alpha$-pinen and myristicin.

Nutmeg mace essential oil has antibacterial activity and inhibition zone diameter of 7.375 for Ecschericia coli and $9.25 \mathrm{~mm}$ for Stapylococus aureus in $7.5 \%$ concentration.

\section{REFERENCES}

Agusta A. 2000. Minyak Atsiri Tumbuhan Tropika Indonesia. ITB . Bandung.

Ansory et al., 2015. Perbandingan Kualitas Minyak Atsiri Pala Hasil Isolasi dari Bagian-Bagian Buah Pala Berdasarkan Kadar Miristisin. Jurnal Farmasi Indonesia. Vol hal 127 - 136, hal $127-136$

Ansory HM. 2014. Sintesis Turunan Kalkon dari Miristisin Minyak Pala dan Uji Potensi Sebagai Penghambat UV-A (Tesis). Yogyakarta. Universitas Gadjah Mada.

Bakri Zakia et al., 2015. Deteksi Keberadaan Bakteri Escherichia coli 0157:H7 pada Feses Penderita dengan Metode Kultur dan PCR. JST Kesehatan 5:184192.

Gupta et al., 2008. Antimicrobial activity of some herbal oils against common food- borne pathogens. African Journal of Microbiology Research Vol.(2) pp. 258-261.

Hidayati., Nur., Hanifia Ilmawati., dan Efani Sara. 2015. Penyulingan Minyak Biji Pala: Pengaruh Ukuran Bahan, Waktu dan Teknan Penyulingan Terhadap Kualitas dan Randemen Minyak. Simposium Nasional Rapi XIV -2015 FT UMS. 220-226.

Ji YL., Wansu P. 2011. Anti-Inflammatory Effect of Myristicin on RAW 264.7 Macrophages Stimulated with Polyinosinic- Polycytidylic Acid. Molecules. Vol.16.p.7132-7142.

Melliawati Ruth. 2009. Escherichia coli dan Kehidupan Manusia. Jurnal Bio Trensds 4.

Medeiros., Aristides Leite et al., 2007. Inhibitory effect of $\beta$-pinene, $\alpha$-pinene and eugenol on the growth of potential infectious endocarditis causing Grampositive bacteria. Brazilian Journal of Pharmaceutical Sciences. vol. 43, n. 1, jan./mar., 2007.

Pratiwi., Sylfia T. 2008. Mikrobiologi Farmasi. Erlangga. Jakarta.

Rachmi. Widya., Adel Zamri., Yuharmen. 2014. Perbandingan Isolasi Minyak Atsiri Biji Pala (Myristica fragans Houtt) Cara Hidrodistilasi Microwave dan Konvensional Serta Uji Aktivitas Antibakteri dan Antioksidan. JOM FMIPA. Vol.1 edisi Oktober 2014:335343.

Sophia G. Sipahelut., Ivonne Telussa. 2011. Karakteristik Minyak Atsiri Dari Daging Buah Pala Melalui Berbagai Teknologi Proses. Jurnal Teknologi Hasil Pertanian ,Vol 4 , 126-134.

Wonorahardjo., Surjani. 2016. MetodeMetode Pemisahan Kimia Sebuah Pengantar. PT Indeks. Jakarta. 